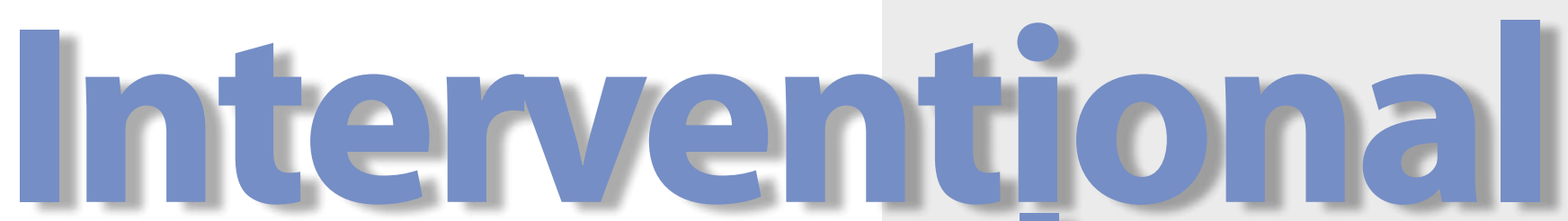

6th Annual Meeting of the

\title{
Society of Vascular and Interventional Neurology
}

October 26-27, 2013, Houston, Tex.

\section{Abstracts}

Guest Editor

Dileep R. Yavagal, Miami, Fla.

Official Journal of:

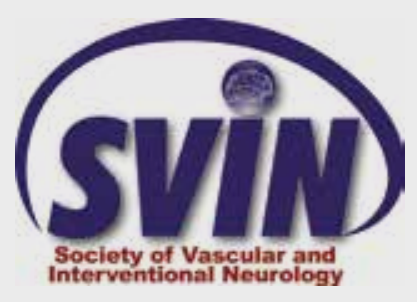




\title{
An excellent overview on current stroke syndromes, including problematic clinical pictures
}

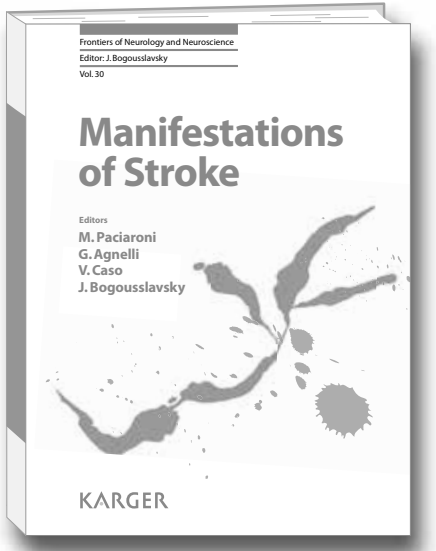

\section{Manifestations of Stroke}

\author{
Editors \\ Maurizio Paciaroni \\ Giancarlo Agnelli \\ Valeria Caso \\ Julien Bogousslavsky
}

\section{Contents}

Preface: Paciaroni, M.; Agnelli, G.; Caso, V.; Bogousslavsky, J.

\section{Neurologic and Other Disorders}

Motor Syndromes: Corea, F.; Micheli, $\mathbf{S}$.

Sensory Syndromes: Klingner, C.M.; Witte, O.W.; Günther, $A$.

Headache: Cittadini, E.; Caso, $\boldsymbol{V}$.

Eye Movement Abnormalities: Moncayo, J.; Bogousslavsky, J.

Visual Dysfunctions: Paciaroni, $M$.; Bogousslavsky, J.; Caso, V.; Agnelli, G.

Dizziness and Vertigo: Della-Morte, $\boldsymbol{D}$.; Rundek, $\boldsymbol{T}$. Auditory Dysfunction: Baldi, A.; Tenaglia, S.; D'Anna, $S$.

Seizures: Alberti, $\boldsymbol{A}$.

Impaired Consciousness: Acciarresi, M.; Alberti, A.

Sleep Changes: $\boldsymbol{A} / \boldsymbol{b}$ erti, $\boldsymbol{A}$.

Aphasia and Other Language Disorders: de Freitas, G.R.

Confusion, Agitation and Delirium: Martin, J.J.

Executive Dysfunctions and Frontal Syndromes: Seniów, J.

Memory Dysfunction: Amici, $\mathbf{S}$.

Neurobehavioral Syndromes:

Piechowski-Jozwiak, B.; Bogousslavsky, J.

Right Hemisphere Syndromes: Palmerini, F.;

Bogousslavsky, J.

Post-Stroke Dementia and Cognitive Impairment: Pasi, M.; Poggesi, A.; Salvadori, E.; Pantoni, L.

Mood Disorders after Stroke: Carota, $\boldsymbol{A}_{\text {.; }}$ Bogousslavsky, J.

Agnosia, Apraxia, Callosal Disconnection and Other Specific Cognitive Disorders: Acciarresi, $\boldsymbol{M}$.

Muscle, Peripheral Nerve and Autonomic Changes: Pezzella, F.R.; Anticoli, S.; Pozzessere, C.

Dysarthria and Mutism: Sternic, N.; Mijajlovic, M.; Tomic, G.; Pavlovic, A.

Dysphagia - Pathophysiology, Diagnosis and Treatment: Cecconi, E.; Di Piero, V.

Ventilatory Disorders: Silvestrelli, G.; Lanari, A.; Droghetti, $A$.

Lacunar versus Non-Lacunar Syndromes: Micheli, S.; Corea, F.

Topographic Syndromes

Arterial Territories of the Human Brain: Tatu, L.; Moulin, T.; Vuillier, F.; Bogousslavsky, J.

Superficial Middle Cerebral Artery Territory Infarction: Delgado, M.G.; Bogousslavsky, J.

Lenticulostriate Infarction: Decavel, P.; Vuillier, F.; Moulin, $\boldsymbol{T}$.

Anterior Cerebral Artery and Heubner's Artery Territory Infarction: Toyoda, $\boldsymbol{K}$.
Anterior Choroidal Artery Territory Infarction: Pezzella, F.R.; Vadalà, $\boldsymbol{R}$.

Posterior Cerebral Artery Territory Infarction: Cereda, C.; Carrera, E.

Thalamic Infarcts and Hemorrhages: Amici, $\boldsymbol{S}$.

Caudate Infarcts and Hemorrhages:

Pellizzaro Venti, M.; Paciaroni, M.; Caso, V.

Putaminal Hemorrhages: Ghetti, $\mathbf{G}$.

Lobar Hemorrhages: Lunardi, $P$.

Subarachnoid and Intraventricular Hemorrhage: Venti, $M$.

Large Middle Cerebral Artery and Panhemispheric Infarction: Giossi, A.; Volonghi, I.; Del Zotto, E.; Costa, P.; Padovani, A.; Pezzini, A.

Midbrain Infarcts and Hemorrhages: Moncayo, J.

Pontine Infarcts and Hemorrhages: Moncayo, $J$.

Medullary Infarcts and Hemorrhages: Balucani, C.; Barlinn, $\boldsymbol{K}$.

Cerebellar Infarcts and Hemorrhages: Venti, $\boldsymbol{M}$.

Extended Infarcts in the Vertebrobasilar Territory: Santalucia, $\boldsymbol{P}$.

Border-Zone and Watershed Infarctions: D'Amore, C.; Paciaroni, $\boldsymbol{M}$.

Acute and Chronic Carotid Occlusion Syndromes: Lanari, A.; Silvestrelli, G.

Venous Ischemic Syndromes: Ageno, W.; Dentali, $\boldsymbol{F}$. Spinal Cord Syndromes: Novy, J.

\section{Frontiers of Neurology and Neuroscience,} Vol. 30

Series Editor: Bogousslavsky, J. (Montreux) ISSN 1660-4431 / e-ISSN 1662-2804

Manifestations of Stroke

Editors: Paciaroni, M.; Agnelli, G.; Caso, V. (Perugia);

Bogousslavsky, J. (Montreux)

$X+206$ p., 46 fig., 9 in color, 14 tab., hard cover, 2012

CHF 198.- / EUR 165.- / USD 233.00

Prices subject to change

EUR price for Germany, USD price for USA only

ISBN 978-3-8055-9910-8

e-ISBN 978-3-8055-9911-5

\section{$\rightarrow$ Please send:}

$\boldsymbol{\varepsilon}$

Postage and handling free with prepayment

Payment:

- Please charge to my credit card

- $\square$ American Express $\square$ Diners

ᄂ $\square$ MasterCard $\square$ Visa

- Card No.

๑

ర Exp.date

-

- CVV/CVC

( 3 digits in the signature field on the back of Visa and MasterCard)

$\square$ Check enclosed $\square$ Please bill me

Orders may be placed with any bookshop, subscription agency, directly with the publisher or through a Karger distributor.

\section{Fax: +41613061234}

S. Karger AG, P.O. Box, CH-4009 Basel (Switzerland)

E-Mail orders@karger.ch,www.karger.com

Name/Address: 


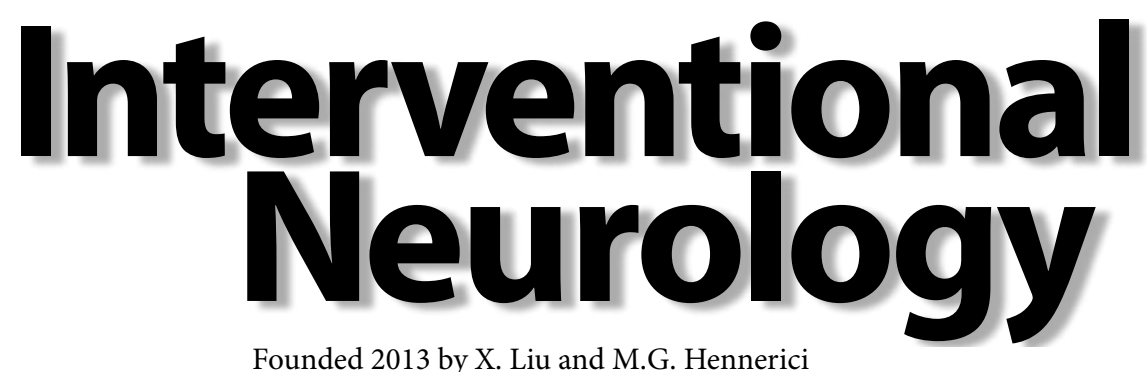

\section{Editors}

\section{Xinfeng Liu}

Jinling Hospital

Nanjing University

Nanjing, China
Michael G. Hennerici

Department of Neurology

University of Heidelberg

Mannheim, Germany

\author{
Raul G. Nogueira \\ Marcus Stroke \& \\ Neuroscience Center \\ Grady Memorial Hospital \\ Atlanta, Ga.
}

\section{Associate Editors}

A. Dávalos, Barcelona

A.J. Furlan, Cleveland, Ohio

R. Gupta, Atlanta, Ga.

R. Higashida, San Francisco, Calif.

G. Xu, Nanjing

S. Yoshimura, Hyogo

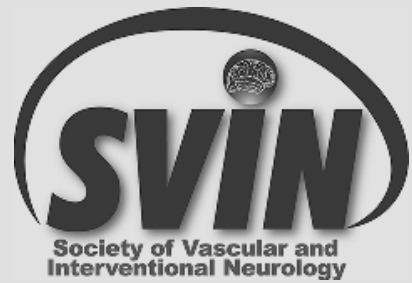

SVIN Representative

Dileep R. Yavagal

\section{Editorial Board}

A. Abou-Chebl, Louisville, Ky.

A.V. Alexandrov, Birmingham, Ala.

R.C. Edgell, Houston, Tex.

A. Harloff, Freiburg

V. Janardhan, Dallas, Tex.

T. Jovin, Pittsburgh, Pa.

P. Khatri, Cincinnati, Ohio

D.S. Liebeskind, Los Angeles, Calif.

T. Leung, Hong Kong

A.R. Massaro, São Paulo

Z. Miao, Beijing

R. Novakovic, Dallas, Tex.

N.S. Rost, Boston, Mass.

J.L. Saver, Los Angeles, Calif.

M. Selim, Boston, Mass.

K.N. Sheth, New Haven, Conn.

B. Yan, Parkville, Vic.

D.R. Yavagal, Miami, Fla.

O.O. Zaidat, Milwaukee, Wisc. 


\section{Interventional Neurology}

\section{Submission \\ Manuscripts written in English are considered and should be submitted online at: \\ www.karger.com/ine}

All manuscripts must be accompanied by a cover letter and copyright signed by all authors.

\section{Conditions}

All manuscripts are subject to editorial review. Manuscripts are received with the explicit understanding that they are not under simultaneous consideration by any other publication. Submission of an article for publication implies transfer of the copyright from the author to the publisher upon acceptance. Accepted papers become the permanent property of Interventional Neurology and may not be reproduced by any means, in whole or in part, without the written consent of the publisher. It is the author's responsibility to obtain permission to reproduce illustrations, tables, etc. from other publications.

\section{Types of Articles}

Editorials

Original Papers

Reviews

Reviews in which a specific field is reviewed through an exhaustive literature survey. An Abstract is required and should be divided into Background, Summary and Key Messages. Review Articles should consist of a maximum of 4,000 words.

\section{Disclosure Statement}

Authors are required to disclose any sponsorship or funding arrangements relating to their research and all authors should disclose any possible conflicts of interest. Disclosure statements will be published at the end of the text of the article.

Ethics

Published research must comply with the guidelines for human studies and animal welfare regulations. Authors should state that subjects have given their informed consent and that the study protocol has been approved by the institute's committee on human research. Further, they should also state that animal experiments conform to institutional standards. Authors are required to declare the approval codes obtained from the corresponding ethical committee on human and/or animal research.

\section{Plagiarism Policy}

Whether intentional or not, plagiarism is a serious violation. We define plagiarism as a case in which a pape reproduces another work with at least $25 \%$ similarity and without citation.

If evidence of plagiarism is found before/after acceptance or after publication of the paper, the author will be offered a chance for rebuttal. If the arguments are not found to be satisfactory, the manuscript will be retracted and the author sanctioned from publishing papers for a period to be determined by the responsible Editor(s).

\section{Arrangement}

The manuscript should conform to the following order: title page, abstract and key words, body, acknowledgments, references, figure legends, tables and figures. Manuscripts should be written in high-quality English suitable for effective communication to a professiona medical audience. Authors who are not native speakers of English sometimes receive negative comments from referees or editors about the English-language usage in their manuscripts, and these problems can contribute to the decision to reject a paper. To help reduce the possibility of such problems, we strongly encourage such authors (i) to have their manuscript reviewed for clarity by a colleague whose native language is English and/or (ii) to use one of the many English language editing services that are available via the Web.
All pages, including the figure legends, should be numbered in sequence, and the first author's name should appear at the upper right corner of each page. Papers not conforming to the journal style will be returned without review. Title page: The first page of each paper should indicate a concise title of no more than 150 characters, all authors' names (first name and surname), authors' institutional affiliations, and a short title for use as running head.

Corresponding author: The exact postal address of author(s) to whom correspondence, proofs, and reprint requests should be sent, including the postal code, must be given at the bottom of the title page. Please also supply phone number and e-mail address.

Abstract: Submit the abstract on a separate page. The abstract should be less than 300 words.

Key words: Following the abstract, an alphabetical list of five key words that reflect the content of the paper should be given.

Abstract of Reviews: Should be divided into the following subsections: Background, Summary and Key Messages. The Background should provide a brief clinical context for the review and is followed by the Summary, which should include a concise description of the main topics covered in the text. The Key Messages encapsulate the main conclusions of the review.

Footnotes: Avoid footnotes.

Tables and illustrations: Tables and illustrations (both numbered in sequential Arabic numerals) should be prepared as separate files. Tables require a brief and concise heading. Figures require a legend, prepared as a separate page, after references. Please use scale markers for electron micrographs, and indicate the type of stain used. For the reproduction of illustrations, only good drawings and original photographs can be accepted; negatives or photocopies cannot be used. Due to technical reasons, figures with a screen background should not be submitted. When possible, group several illustrations in one block for reproduction $(\max$. size $180 \times 223 \mathrm{~mm}$ ) or provide crop marks. Electronically submitted b/w half-tone and color illustrations must have a final resolution of $300 \mathrm{dpi}$ after scaling, line drawings one of 800-1,200 dpi.

References: In the text identify references by Arabic numerals [in square brackets]. Material submitted for publication but not yet accepted should be noted as [unpublished data] and not be included in the reference list. The list of references should include only those publications which are cited in the text. Do not alphabetize; number references in the order in which they are first mentioned in the text. The surnames of the authors followed by initials should be given. There should be no punctuation other than a comma to separate the authors. Preferably, please cite all authors. Abbreviate journal names according to the Index Medicus system. Also see International Committee of Medical Journal Editors: Uniform requirements for manuscripts submitted to biomedical journals (www.icmje.org).

Examples

(a) Papers published in periodicals: Chatel J-M, Bernard $\mathrm{H}$, Orson FM: Isolation and characterization of two complete Ara h 2 isoforms cDNA. Int Arch Allergy Immunol 2003;131:14-18.

(b) Papers published only with DOI numbers:

Theoharides TC, Boucher W, Spear K: Serum interleukin-6 reflects disease severity and osteoporosis in mastocytosis patients. Int Arch Allergy Immunol DOI: $10.1159 / 000063858$

(c) Monographs: Matthews DE, Fare-well VT: Using and Understanding Medical Statistics, ed 3, revised. Basel, Karger, 1996.

(d) Edited books: DuBois RN: Cyclooxygenase-2 and colorectal cancer; in Dannenberg AJ, Dubois RN (eds):
COX-2. Prog Exp Tum Res. Basel, Karger, 2003, vol 37, pp 124-137.

Reference Management Software: Use of EndNote is recommended for easy management and formatting of citations and reference lists.

\section{Digital Object Identifier (DOI)}

S. Karger Publishers supports DOIs as unique identifiers for articles. A DOI number will be printed on the title page of each article. DOIs can be useful in the future for identifying and citing articles published online without volume or issue information. More information can be found at www.doi.org.

\section{Author's Choice ${ }^{\mathrm{TM}}$}

Karger's Author's Choice ${ }^{\mathrm{TM}}$ service broadens the reach of your article and gives all users worldwide free and full access for reading, downloading and printing at www. karger.com. The option is available for a one-time fee of CHF 3,000.-, which is a permissible cost in grant allocation. More information can be found at www.karger com/authors_choice.

\section{Supplementary Material}

Supplementary material is restricted to additional data that are not necessary for the scientific integrity and conclusions of the paper. Please note that all supplementary files will undergo editorial review and should be submitted together with the review article. The Editors reserve the right to limit the scope and length of the supplementary material. Supplementary material must meet production quality standards for Web publication without the need for any modification or editing. In general supplementary files should not exceed $10 \mathrm{Mb}$ in size. All figures and tables should have titles and legends and all files should be supplied separately and named clearly. Acceptable files and formats are: Word or PDF files, Excel spreadsheets (only if the data cannot be converted properly to a PDF file), and video files (.mov, .avi, .mpeg).

\section{NIH-Funded Research}

The U.S. National Institutes of Health (NIH) mandates under the NIH Public Access Policy that final, peer-reviewed manuscripts appear in its digital database within 12 months of the official publication date. As a service to authors, Karger submits your manuscript on your behalf to PubMed Central (PMC) immediately upon publication. It usually receives a PMCID within approximately a month and will appear in PMC after 12 months. For those selecting our premium Author's Choice ${ }^{\mathrm{TM}}$ service, the usual embargo will be overridden, accelerating the accessibility of your work.

\section{Self-Archiving}

Karger permits authors to archive their pre-prints (i.e. pre-refereeing) or post-prints (i.e. final draft post-refereeing) on their personal or institution's servers, provided the following conditions are met: Articles may not be used for commercial purposes, must be linked to the publisher's version, and must acknowledge the publisher's copyright. Authors selecting Karger's Author's Choice ${ }^{\mathrm{TM}}$ feature, however, are also permitted to archive the final, published version of their article, which includes copyediting and design improvements as well as citation links.

\section{Proofs}

Unless indicated otherwise, proofs are sent to the corresponding author and should be returned with the least possible delay. Alterations other than the correction of printer's errors are charged to the author.

\section{Reprints}

Order forms and a price list are sent with the proofs. Orders submitted after the issue is printed are subject to considerably higher prices.

\section{KARGER}

E-Mail karger@karger.com www.karger.com
(C) 2013 S. Karger AG, Basel 


\section{Interventional Neurology}

ISSN Print Edition: 1664-9737

ISSN Online Edition: 1664-5545

Journal Homepage: www.karger.com/ine

Publication Data: 'Interventional Neurology' is published 4 times a year. Volume 2 with 4 issues appears in 2013 .

Copyright: (c) 2013 S. Karger AG, Basel (Switzerland). All rights reserved. No part of this publication may be translated into other languages, reproduced or utilized in any form or by any means, electronic or mechanical including photocopying, recording, microcopying, or by any information storage and retrieval system, without permission in writing from the publisher or, in the case of photocopying, direct payment of a specified fee to the Copyright Clearance Center.

Disclaimer: The statements, opinions and data contained in this publication are solely those of the individual authors and contributors and not of the publisher and the editor(s). The appearance of advertisements in the journal is not a warranty, endorsement, or approval of the products or services advertised or of their effectiveness, quality or safety. The publisher and the editor(s) disclaim responsibility for any injury to persons or property resulting from any ideas, methods, instructions or products referred to in the content or advertisements.
Subscription Rates: Subscriptions run for a full calendar year. Prices are given per year. Personal subscription:

Print or Online

CHF 730.-

EUR 589.-

USD 723.00

CHF 778.-

EUR 628.-

USD 771.00

postage and handling (added to print and print+online)

CHF 28.80 Europe, CHF 41.60 Overseas

EUR 22.40

USD 38.40

Institutional subscription:

Print or Onlin

CHF 1460.-

EUR 1177.-

Print+Online combined

USD 1446.00

CHF 1606.

EUR 1295.-

postage and handling (added to print and print+online)

CHF 36.- Europe, CHF 52.- Overseas

EUR 28.-

USD 48.00

Airmail surcharge: CHF 35.- / USD 33.00
Back Volumes and Single Issues: Information on availability and prices of single print issues and print or electronic back volumes can be obtained from Customer Service at service@karger.ch.

Bibliographic Indices: This journal is regularly listed in bibliographic services.

Photocopying: This journal has been registered with the Copyright Clearance Center (CCC), as indicated by the code appearing on the first page of each article. For readers in the US, this code signals consent for copying of articles for personal or internal use, or for the personal or internal use of specific clients, provided that the stated fee is paid per copy directly to

Copyright Clearance Center Inc.

222 Rosewood Drive

Danvers, MA 01923 (USA)

A copy of the first page of the article must accompany payment. Consent does not extend to copying for general distribution, for promotion, for creating new works, or for resale. In these cases, specific written permission must be obtained from the copyright owner,

S. Karger AG, P.O. Box

$\mathrm{CH}-4009$ Basel (Switzerland)

\begin{tabular}{|c|c|c|c|}
\hline $\begin{array}{l}\text { Subscription Orders: } \\
\text { Orders can be placed at agencies, } \\
\text { bookstores, directly with the Publisher } \\
\text { S. Karger AG } \\
\text { Medical and Scientific Publishers } \\
\text { Allschwilerstrasse } 10 \\
\text { CH-4009 Basel } \\
\text { Switzerland } \\
\text { t: }+41613061111 \\
\text { f: +41 } 613061234 \\
\text { e: karger@karger.com } \\
\text { w: www.karger.com } \\
\text { (for courier services only: } \\
\text { Allschwilerstrasse } 10 \\
\text { CH-4055 Basel) }\end{array}$ & $\begin{array}{l}\text { or further Karger offices } \\
\text { or representatives: } \\
\text { Germany } \\
\text { S. Karger GmbH } \\
\text { Postfach } \\
\text { 79095 Freiburg } \\
\text { Deutschland } \\
\text { (Hausadresse: Wilhelmstrasse 20A, } \\
\text { 79098 Freiburg) } \\
\text { t: +49 761 } 452070 \\
\text { f: +49 761 } 4520714 \\
\text { e: information@karger.de } \\
\text { w: www.karger.de } \\
\text { Japan } \\
\text { Karger Japan, Inc. } \\
\text { Shiba Daimon Asahi Bldg. 2F } \\
\text { 1-2-23 Shiba Daimon } \\
\text { Minato-ku } \\
\text { Tokyo } 105-0012 \\
\text { Japan } \\
\text { t: +81 } 364356242 \\
\text { f: +81 } 364356244 \\
\text { e: publisher@karger.jp } \\
\text { w: www.karger.jp }\end{array}$ & $\begin{array}{l}\text { USA } \\
\text { S. Karger Publishers, Inc. } \\
26 \text { West Avon Road } \\
\text { P.O. Box 529 } \\
\text { Unionville, CT } 06085 \\
\text { USA } \\
\text { Toll free: }+18008285479 \\
\text { t: }+18606757834 \\
\text { f: }+18606757302 \\
\text { e: karger@snet.net } \\
\text { France } \\
\text { Enter \& Read } \\
\text { Albertine Luginbuhl } \\
\text { 23, rue du Départ, boite } 37 \\
75014 \text { Paris } \\
\text { France } \\
\text { t: +33 (0) } 681047685 \\
\text { e: albertineluginbuhl@orange.fr } \\
\text { South East Asia, China and Taiwan } \\
\text { Karger Regional Office (Malaysia) } \\
\text { CEO Suite Kuala Lumpur } \\
\text { Quill 7, 27th Floor } \\
\text { Jalan Stesen Sentral } 5 \\
\text { KL Sentral } \\
\text { Kuala Lumpur } 50470 \\
\text { Malaysia } \\
\text { t: +60 } 327766803 \\
\text { f: +60 } 327766999 \\
\text { e: service@karger.cn }\end{array}$ & $\begin{array}{l}\text { Karger China } \\
\text { West/5F, China Life Tower } \\
\text { No.16, Chao Wai Street } \\
\text { Chaoyang District } \\
\text { Beijing } 100020 \\
\text { China } \\
\text { t: }+861058771408 \\
\text { f: +86 } 1058771120 \\
\text { e: service@karger.cn; r.chew@karger.cn } \\
\text { w: www.karger.cn } \\
\text { India, Bangladesh, Sri Lanka } \\
\text { Karger India } \\
\text { Plot No. 17, Yusuf Sarai Market } \\
\text { B.L. Glass Building, 2nd Floor } \\
\text { Sri Aurobindo Marg } \\
\text { New Delhi } 110016 \\
\text { India } \\
\text { t: +91 } 1146029633 \\
\text { f: +91 } 1146029634 \\
\text { c: +91 } 9891052128 \\
\text { e: r.kumar@kargerindia.com } \\
\text { w: www.karger.com }\end{array}$ \\
\hline
\end{tabular}

Change of Address:

Both old and new address should be sent

to the subscription source.

\section{KARGER}

E-Mail karger@karger.com www.karger.com
(C) 2013 S. Karger AG, Basel

The Journal Home Page is available at: www.karger.com/ine 


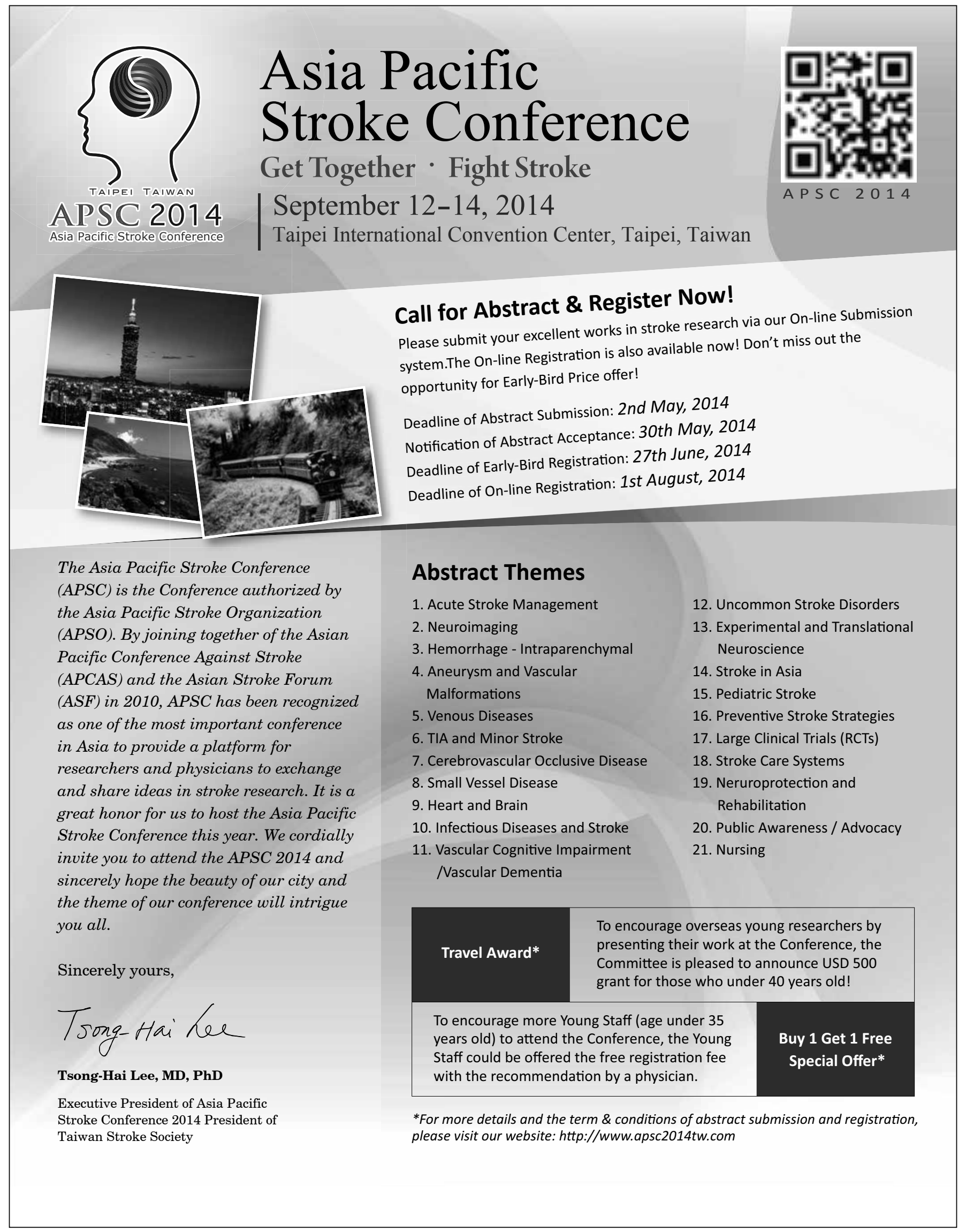




\section{Contents}

See the journal website for contents

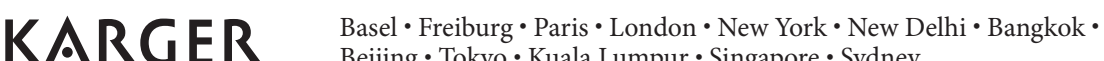
Beijing $\cdot$ Tokyo $\cdot$ Kuala Lumpur $\cdot$ Singapore $\cdot$ Sydney 


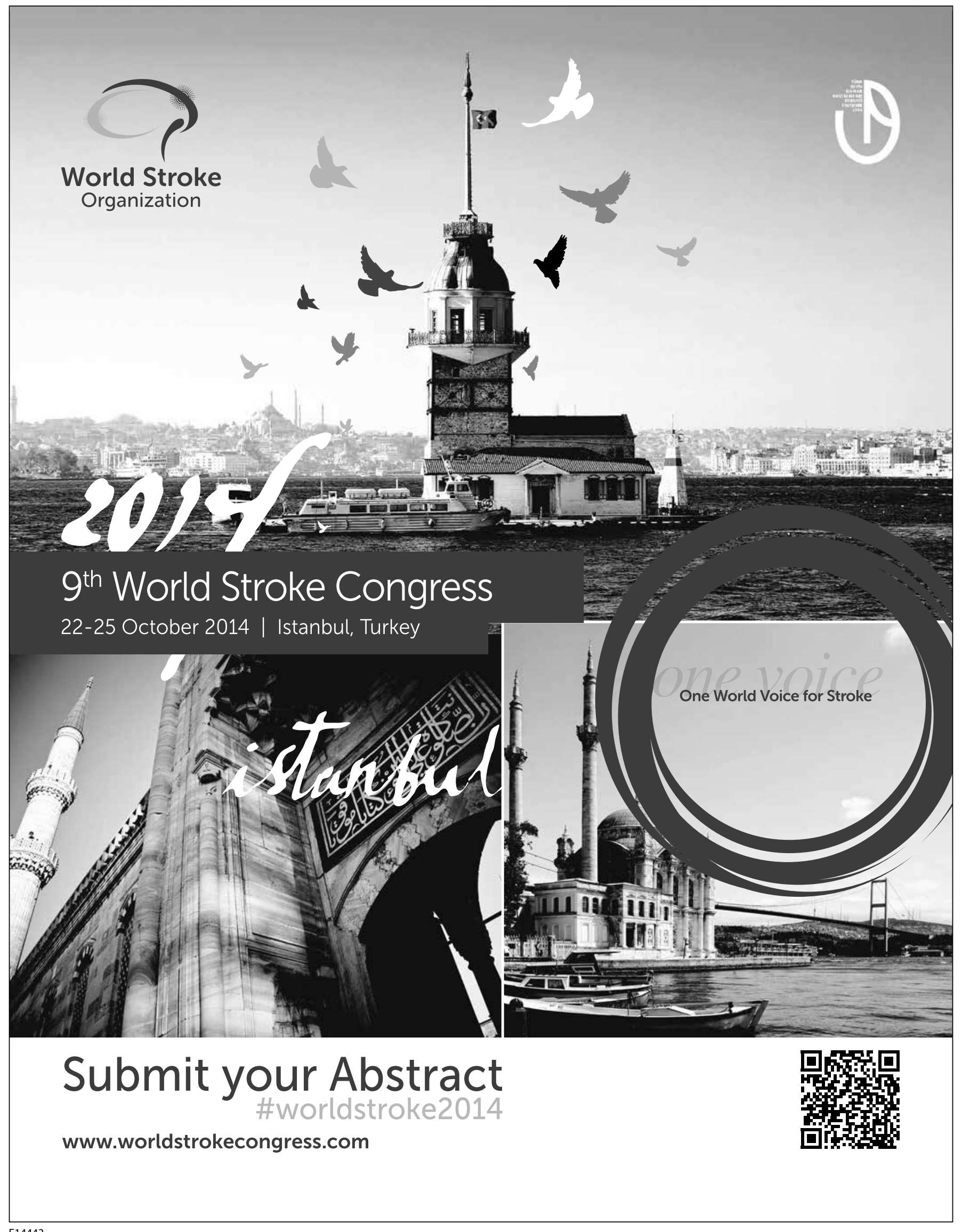




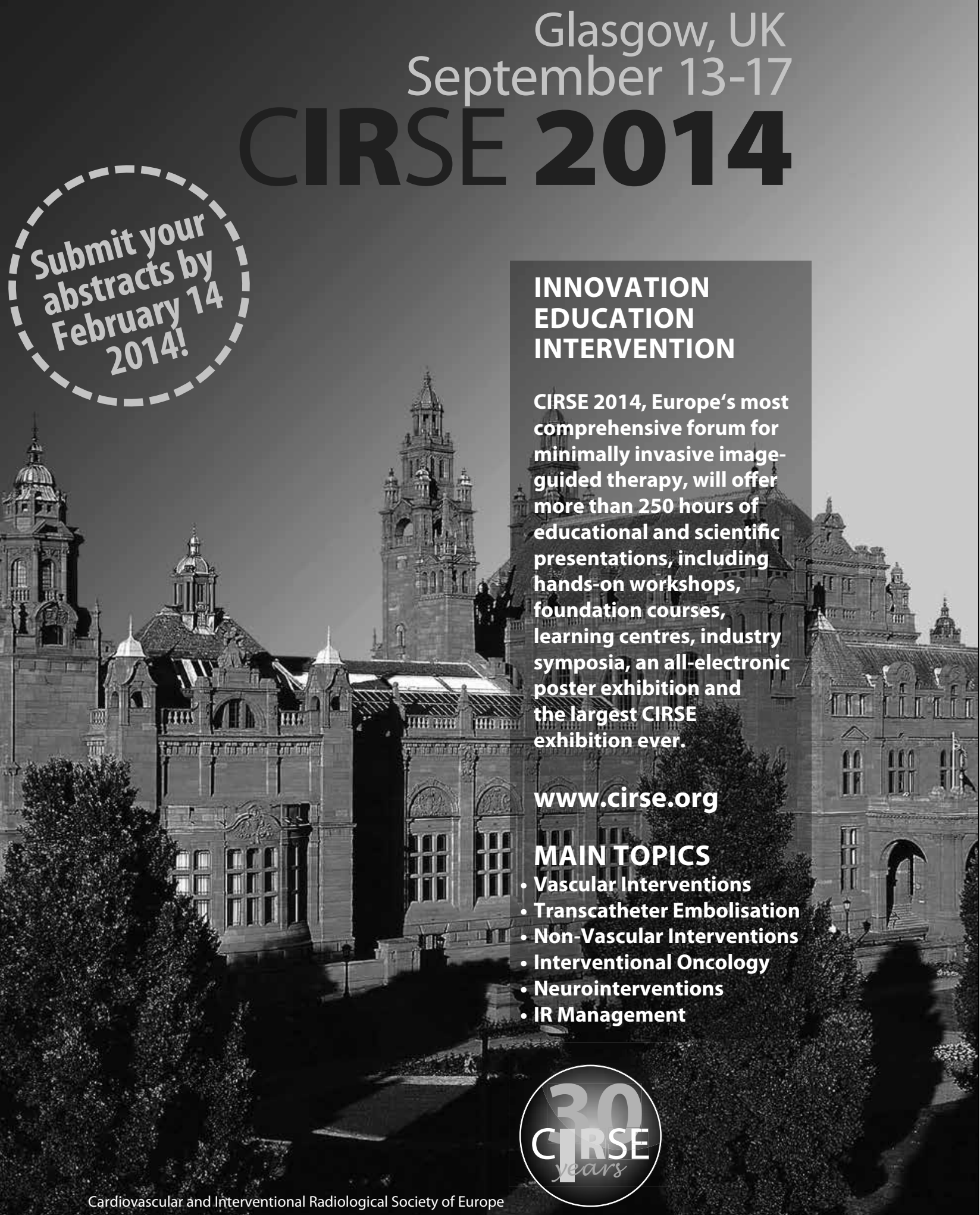




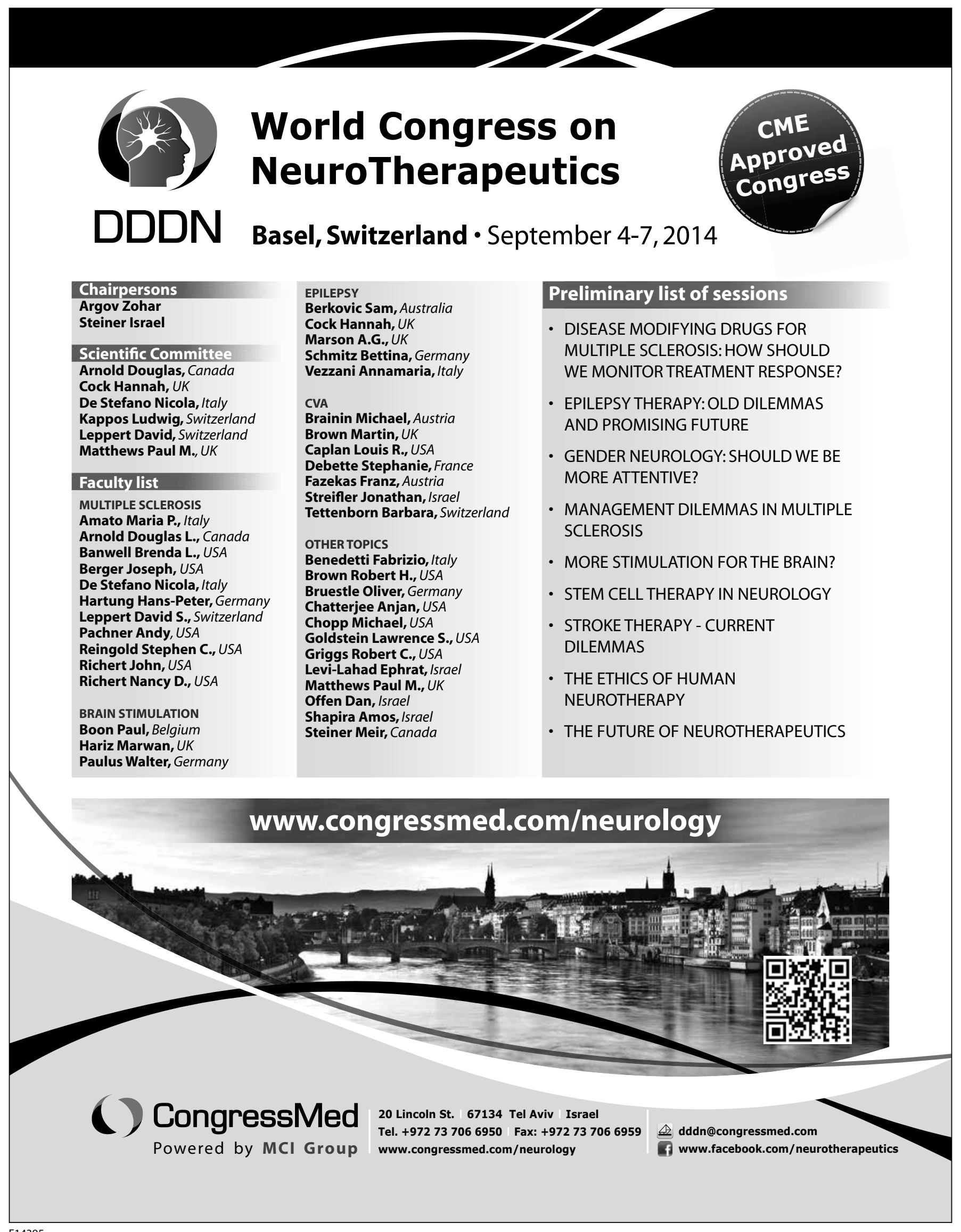




\section{JOINT CONGRESS ISTANBUL 2014}

ISTANBUL, TURKEY, 31 MAY - 3 JUNE 2014

EUROPEAN FEDERATION OF NEUROLOGICAL SOCIETIES EUROPEAN NEUROLOGICAL SOCIETY

We look forward to welcoming you to Istanbul and this unique Congress! Abstract submission deadline: 8 January 2014
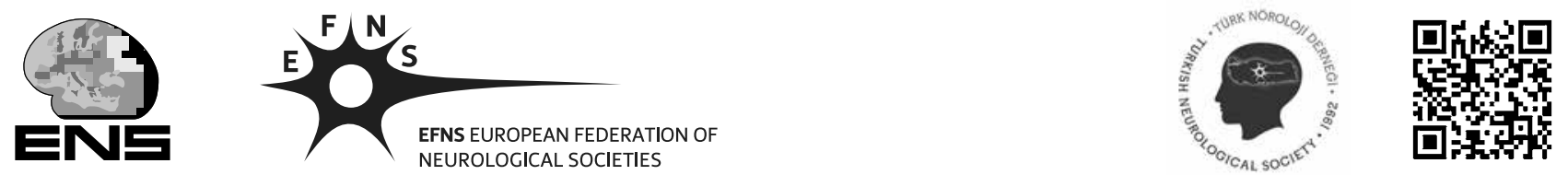


\section{The only international journal devoted to the study of neurological disease distribution and determinants of frequency in human populations}

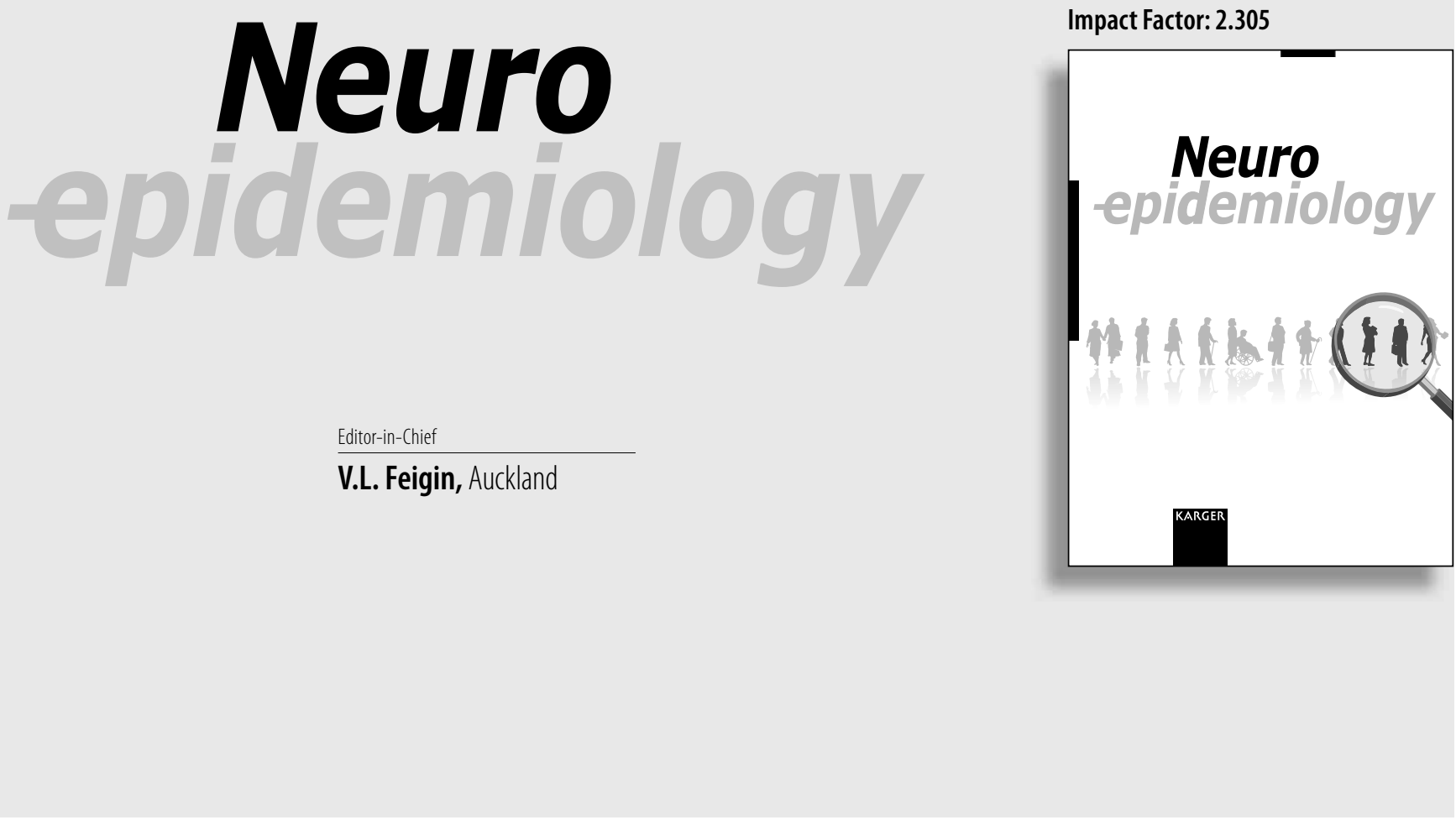

More information at

\section{www.karger.com/ned}

- Pay-per-View and Subscriber Access to Full Text

- Full Table of Contents

- Full Editorial Board

- Free Abstracts and Selected Articles

- Online Sample Issue

- Submission/Guidelines for Authors

- Subscription Details

- Free Alert Service

- Online Library Recommendation

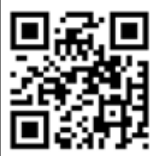

Neuroepidemiology

2014: Volumes 42, 43

4 issues per volume

Language: English

ISSN 0251-5350 (print)

ISSN 1423-0208 (online)

\section{Selected contributions}

- Incidence and Prevalence of Multiple Sclerosis in the Americas:

A Systematic Review: Evans, C. (Vancouver, B.C./Saskatoon, Sask.); Beland, S.-G.; Kulaga, S.; Wolfson, C. (Montréal, Que.); Kingwell, E. (Vancouver, B.C.); Marriott, J. (Winnipeg, Man.); Koch, M. (Calgary, Alta.); Makhani, N. (Toronto, Ont.); Morrow, S. (London, Ont.); Fisk, J. (Calgary, Alta./Halifax, N.S.); Dykeman, J.; Jetté, N.; Pringsheim, T. (Calgary, Alta.); Marrie, R.A. (Winnipeg, Man.)

- Prevalence of Traumatic Brain Injury in the General Adult Population: A Meta-Analysis: Frost, R.B.; Farrer, T.J.; Primosch, M.; Hedges, D.W. (Provo, Utah)

- Interleukin 6 Plasma Concentration Associates with Cognitive Decline: The Northern Manhattan Study: Economos, A.; Wright, C.B. (Miami, Fla.); Moon, Y.P. (New York, N.Y.); Rundek, T. (Miami, Fla.); Rabbani, L.; Paik, M.C. (New York, N.Y.); Sacco, R.L. (Miami, Fla.); Elkind, M.S.V. (Miami, Fla./New York, N.Y.)

- Epidemiological and Clinical Features of Moyamoya Disease in the USA: Kainth, D.; Chaudhry, S.A.; Kainth, H.; Suri, F.K.; Qureshi, A.I. (Minneapolis, Minn.)

- The Utility of Administrative Data for Surveillance of Comorbidity in Multiple Sclerosis: A Validation Study: Marrie, R.A.; Yu, B.N.; Leung, S.; Elliott, L.; Caetano, P. (Winnipeg, Man.); Warren, S. (Edmonton, Alta.); Wolfson, C. (Montreal, Que.); Patten, S.B. (Calgary, Alta.); Svenson, L.W. (Edmonton, Alta./Calgary, Alta.); Tremlett, H. (Vancouver, B.C.); Fisk, J. (Halifax, N.S.); Blanchard, J.F. (Winnipeg, Man.) for the CIHR Team in the Epidemiology and Impact of Comorbidity on Multiple Sclerosis
Neuroepidemiology is the only internationally recognised peer-reviewed periodical devoted to descriptive, analytical and experimental studies in the epidemiology of neurologic disease. The scope of the journal expands the boundaries of traditional clinical neurology by providing new insights regarding the etiology, determinants, distribution, management and prevention of diseases of the nervous system. In order to meet the demands of the ever increasing pace in research, Neuroepidemiology is committed to reduce its online publication span to approx. six weeks after acceptance: papers will be published online first, and their printed version will be included in the next scheduled issue. The journal enjoys a high scientific reputation with a continually increasing impact factor and an equally high circulation. 


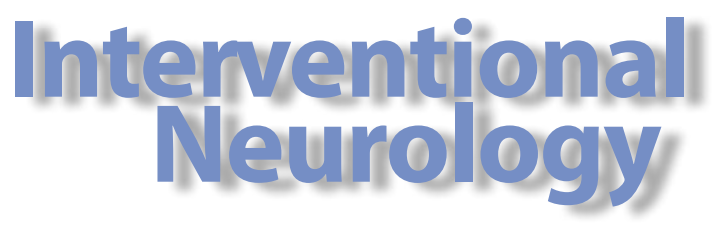

\author{
VII Contents \\ IX Schedule of Events
}

Abstracts

57 6th Annual Meeting of the Society of Vascular and Interventional Neurology October 26-27, 2013, Houston, Tex.

Guest Editor: Yavagal, D.R. (Miami, Fla.)

\title{
96 Author Index
}

\section{KARGER}

